A REVISION OF THE SPECIES OF CYCLOSTREMATID皮 AND LIOTIID王 OCCURRING IN THE PERSIAN GULF AND NORTH ARABIAN SEA.

By J. Cosmo Melvill, M.A., F.L.S.

Read 8th December, 1905.

PLATE III.

More than four years have now elapsed since a catalogue of those species of Liotia and Cyclostrema then known to occur in the Persian Gulf and contiguous seas was published, ${ }^{1}$ and already the number has been nearly doubled. No apology, therefore, seems necessary for again approaching the subject and offering a revision to date. This additional material has been entirely received from Mr. Frederick W. Townsend, whose indefatigable powers of research, both as regards Mollusca and other branches of zoology as well, e.g. ichthyology, have already in their results eclipsed the efforts of previous investigators in this region. As regards this particular instance, the majority of the species now added, three of which are differentiated as new, came from shell-sand dredged in the Gulf of Oman at a considerable depth, a memorable haul indeed, having already brought to light about one hundred species hitherto unknown to science.

It has been a matter of some surprise that no typical species of Teinostoma, A. Ad., has yet occurred. It will be noted the name Vitrinella, C. B. Ad., will be in this paper employed subgenerically, and after much deliberation I believe this the correct course to take. Instituted in the year 1850 by Professor C. B. Adams for a series of small, widely umbilicated, often hyaline, mostly smooth, spiral shells from California and other West American shores, Vitrinella was much added to by Dr. Philip Carpenter in his Mazatlan Catalogue, and subsequently by $\mathrm{Mr}$. Andrew Garrett in dealing with species from the Pacific Isles. ${ }^{2}$ At the best, however, it ranks as an obscure genus, and consists, we believe, in greater part, of an 'olla podrida,' from which several Cyclostremata and Adeorbes might be extracted. But few are figured, and many have as their types unique dead dredged examples, confessedly imperfect, not easy of access, and therefore, from a scientific point of view, comparatively worthless.

It may not be generally known that the celebrated author of "Peter Simple," “Midshipman Easy," etc., Captain F. Marryat, C.B., F.R.S., was the founder of the genus Cyclostrema in the year 1818, his type being the rare C. cancellatum, ${ }^{3}$ Marryat, from the Philippines.

1 Proc. Zool. Soc., vol. ii (1901), pp. 345-347.

2 Proc. Acad. Nat. Sci. Philadelphia, 1873, p. 213, pl. xxi, figs. 13-17.

3 Captain Marryat considered the genus feminine, his type being given as C. cancellata, but if derived from $\kappa \dot{v} \kappa \lambda o s$ and $\tau \rho \hat{\eta} \mu \alpha$, as is probable, it must be of the neuter gender. 
In conclusion, I would tender my best acknowledgements to Mr. R. Bullen Newton, F.G.S., for information as to fossil species of the families under discussion; likewise to Mr. Edgar A. Smith, I.S.O., and Mr. Ernest R. Sykes, F.L.S.

\section{Family CYCLOSTREMATIDE.}

\section{Genus CYCLOSTREMA, Marryat. ${ }^{1}$}

\section{Cyclostrema annellariom, Melvill \& Standen.}

Cyclostrema annellarium, Melvill \& Standen: Ann. \& Mag. Nat. Hist., vol. xii (1903), p. 292.

Hab.-Gulf of Oman, lat. $24^{\circ} 58^{\prime} \mathrm{N}$., long. $56^{\circ} 54^{\prime}$ E., 156 fathoms.

Distinguishable by its rounded longitudinal riblets, twenty-four in number on the last whorl, the interstitial surface being mieroscopically spirally striate.

\section{Cyclostrema carinatum, H. Adams.}

Cyclostrema carinatum, H. Adams: Proc. Zool. Soc., 1873, p. 207, pl. xxiii, fig. 8 .

Hab.-Persian Gulf, lat. $26^{\circ} \cdot 44^{\prime}$ N., long. $52^{\circ} 30^{\prime}$ E., on telegraphcable, 40 fathoms, sand and mud ; also Gulf of Oman, lat. $24^{\circ} 58^{\prime} \mathrm{N}$., long. $56^{\circ} 54^{\prime}$ E., 156 fathoms.

A solid though small species, many spirally ribbed, with smooth interstices, the ribs being incrassate. Mouth on slightly oblique plane. Not very abundant.

\section{Cyclostrema cingulatum, Dunker.}

Cyclostrema cingulatum, Dkr.: Malak. Blätt., vol. vi, p. 225. Dunkeri, Tryon: Man. Conch., vol. x, p. 91.

Hab.-Persian Gulf; Gulf of Oman, lat. $26^{\circ} 23^{\prime}$ N., long. $54^{\circ} 55^{\prime}$ E., 25 fathoms, sand; also Bombay (Abercrombie, 1892).

A somewhat obscure species, thrice strongly earinate on the periphery, below the suture, and around the umbilicus. Shell shining, white. The name cingulatum has been several times employed in this genus. It is a question whether Dunker or Philippi in this have priority.

\section{Cyclostrema cinguliferum, A. Adams.}

Cyclostrema cinguliferum, A. Adams: Proc. Zool. Soc., 1850, p. 43.

Hab.-Karachi.

A species with six acute ribs on the last whorl, white, deeply umbilicate, discoidally depressed. Not common.

5. Crclostrema eburneum, Nevill.

Cyclostrema eburneum, G. \& H. Nevill: Journ. Asiat. Soe. Bengal, vol. xliv, pt. 2, p. 101, pl. viii, figs. $21,22$.

Hab.-Persian Gulf: Bushire, Reshire, Kishm Island. Mekran Coast: Charber, 7 fathoms, sand and mud. 
The thickly keeled periphery, narrow umbilicus, and spirally striated interstices, with sculptured base, distinguish this handsome species, which is large for the genus.

Nearly allied to, if not absolutely identical with, the original type of the genus C. cancellatum, Marryat, which, however, is an Antillean species.

\section{Cyclostrema exigudm, Philippi.}

Cyclostrema exiguum, Philippi : Zeits. für Malak., 1849, p. 25.

$H a b$.- Gulf of Oman, lat. $24^{\circ} 58^{\prime}$ N., long. $56^{\circ} 54^{\prime}$ E., 156 fathoms.

One specimen, without much doubt referable to this species, the type having been described from Aden. It is, though small, an elegant form, the body-whorl being ornamented with four keels, which are crossed by close longitudinal riblets, giving a gemmulate appearance.

\section{Cyclostrema gyalum, Melvill.}

Cyclostrema gyalum, Melvill: Proc. Malac. Soc., vol. vi, p. 54, pl. v, fig. 22 .

Hab.-Gulf of Oman, lat. $24^{\circ} 58^{\prime}$ N., long. $56^{\circ} 54^{\prime}$ E., 156 fathoms.

Very small, but most conspicuous for the thrice-keeled body-whorl, the keels large proportionately and very acute, the umbilicus being particularly profound.

\section{Cyclostrema Henjamense, Melvill \& Standen.}

Cyclostrema Henjamense, Melvill \& Standen : Ann. \& Mag. Nat. Hist., vol. xii (1903), p. 291, pl. xx, fig. 3 .

Hab.-Persian Gulf, Henjam Island, 10 fathoms, amongst coarse sand and broken shells.

This species is on the borderland between the genus in which it is placed and Liotia; the body-whorl is noticeable for its seven carinæ, closely radiately intersected by slanting riblets, beaded at the points of junction.

\section{Cyclostrema micans, A. Adams.}

Cyclostrema micans, A. Ad.: Proc. Zool. Soc., 1850, p. 44. „, pulchella, Dunker: Malak. Blätt., vol. vi (1860), p. 225. Liotia pulchella, Dunker.

Hab.-Karachi (F. W. T.); Bombay (A. Abercrombie).

On the borderland between Liotia and Cyclostrema, the body-whorl possessing three spiral beaded costulæ, the umbilicar region being likewise much decorated with two or three other similar rows, the umbilicus itself being small. Near C. anaglyptum, A. Ad., or C. ocrinium, M. \& S.

\section{Cyclostrema novem-carinatum, n.sp. Pl. III, Figs. $3,3 a$.}

C. testa parva, profunde umbilicata, depresso-orbiculari, alba, parum nitida, anfractibus 5, quorum 2 apicales vitrei, minutissimi, cæteris ad suturas excavatis, antepenultimo et penultimo binis, ultimo anfractu novem carinis (interdum apud suturas duabus minoribus additis), 
præditis, superficie omni radiatim aretissime striata, apertura circulari, intus alba, peristomate paullum incrassato, fere continuo. Alt. 1·25, diam. $3 \mathrm{~mm}$.

$H a b$. - Gulf of Oman, lat. $24^{\circ} 58^{\prime}$ N., long. $56^{\circ} 54^{\prime}$ E., 156 fathoms.

The whole surface of this little species, which is typically and most frequently furnished with nine spiral carinæ on the body-whorl (of which the sutural and inner umbilicar keels are but weakly developed), is minutely radiately, very closely striate, giving it a shagreened and silky appearance.

Though not quite so abundant as C. 5-carinatum, it occurs very frequently in the above dredging, but I have not yet noticed it from other localities.

\section{Cyclostrema ocrinium, Melvill \& Standen.}

Cyclostrema ocrinium, Melvill \& Standen: Proc. Zool. Soc., vol. ii (1901), p. 346, pl. xxii, fig. 1.

Hab.-Persian Gulf, lat. $25^{\circ} 44^{\prime}$ N., long. $52^{\circ} 30^{\prime}$ E. ; likewise on the telegraph cable at 40 fathoms, mud and sand.

I copy the remarks written by myself at the time of description : "This exquisite and very delicate Cyclostrema is slightly comparable with $C$. anaglyptum, A. Ad., from Japan, but is smaller, not so conical, and destitute of spiral ribs. The longitudinal riblets are very close and fine, say, 26 in number on the basal whorl, five-angled, that surrounding the umbilicus at the base being the strongest and most conspicuous. Regular rows of shining gemmæ on the costulæ at the point of the angular projections take the place of spiral liræ; the interstices are plain, vitreous, white; mouth circular, peristome continuous, outer lip crenulate; columellar margin not reflexed over the umbilicus, which is deep and conspicuous."

\section{Cyclostrema prominulum, Melvill \& Standen.}

Cyclostrema prominulum, Melvill \& Standen: Ann. \& Mag. Nat. Hist., vol. xii (1903), p. 292, pl. $\mathrm{xx}$, fig. 6 .

$H a b .-G u l f$ of Oman, lat. $24^{\circ} 58^{\prime}$ N., long. $56^{\circ} 54^{\prime}$ E., 156 fathoms.

One of the rarer species, of which but two or three specimens have occurred. It is conspicuous for being unusually strongly carinate at the periphery of the body-whorl, the rest of the surface being uniformly multilirate.

13. Cyclostrema quadri-carinatum, Melvill \& Standen.

Cyclostrema quadri-carinatum, Melvill \& Standen: Proc. Zool. Soc., vol. ii (1901), p. 346, pl. xxii, fig. 2.

Hab.-Gulf of Oman, lat. $24^{\circ} 49^{\prime}$ N., long. $55^{\circ} 56^{\prime}$ E., 225 fathoms, sand and mud.

This small shell, four-keeled only on the body-whorl, has not yet been found elsewhere. We have till lately confounded it with the next species now to be described, and to which it bears a superficial resemblance. The remarks made (Ann. \& Mag. Nat. Hist., vol. xii, 1903 , p. 293) as to the frequency of $C$. quadri-carinatum must therefore be erased. 


\section{Cyclostrema quinque-carinatum, n.sp. Pl. III, Figs. 1, $1 a$.}

C. testa parva, profunde umbilicata, depresso orbiculari, læviuscula, nitida, albo-lactea, vel, rarissime pallide apud carinas stramineo-tincta, anfractibus 5, quorum duo apicales, minuti, vitrei, cæteris spiraliter acuti-carinatis, carinis paullum excavatis, superficie interstitiali omnino lærissima, nitida, supernis unâ, ultimo anfractu quinque carinis prædito; quarum prima infra suturas secunda et tertia apud medium, quarta peripheriali, quinta circa umbilicum, interdum sed rarissime, sexta apud medium umbilicare (var. sex-carinatum), videnda, apertura rotunda, peristomate fere continuo, vix incrassato, simplice. Alt. 1, diam. $255 \mathrm{~mm}$.

$H a b .-G u l f$ of Oman, lat. $24^{\circ} 58^{\prime}$ N., long. $56^{\circ} 54^{\prime}$ E., 156 fathoms.

Probably the commonest Gastropod in the above most prolific dredging. It is very uniform in size and sculpture, but occasionally possesses an additional keel or stray spiral lira on the umbilicar region (var. 6-carinatum).

15. Cyclostrema solariellum, Melvill. Pl. III, Figs. 5, $5 a$. Cyclostrema solariellum, Melvill: Mem. Manch. Soc., vol. vii (1893), p. 63 , pl. i, fig. 20.

Hab.-Persian Gulf: Fao, Bushire. Gulf of Oman, lat. $26^{\circ} 23^{\prime}$ N., long. $54^{\circ} 55^{\prime} \mathrm{E}$, 25 fathoms, mud; with C. cingulatum, but much more frequent. Karachi, fine and large (F. W. T.); Bombay (Abercrombie). From the last place only worn examples, from one of which the type was described.

This is a puzzling species, having the aspect of a small Torinia. We take the opportunity of refiguring it in two positions, which will render it recognizable at a glance. Allied to C. Marchei, Jousseaume, Rev.Zool., 1872, p. 391, pl. xix, fig. 3, from the East Indies, differing in the umbilicar beading and other points.

\section{Cyclostrema suprenum, Melvill \& Standen.}

Cyclostrema supremum, Melvill \& Standen : Ann. \& Mag. Nat. Hist., vol. xii (1903), p. 291, pl. xx, fig. 4.

Hab.-Persian Gulf, near Fao, and likewise off Bunder Abbas, 5 fathoms, mud bottom.

A very beautiful form, five-whorled, two being apical, the rest cancellated, channelled suturally, the body-whorl being thrice-keeled, with interstices of surface spirally finely striate, about twenty-eight small ribs in all being present. On the base and around the umbilicus the shell is nearly smooth.

\section{Subgenus I: VITRINELLA, C. B. Adams. ${ }^{1}$}

17. Cyclostrema charmophron, ${ }^{2}$ n.sp. Pl. III, Figs. $2,2 a$.

C. testa minutissima, late et profunde umbilicata, tenui, depressodiscoidali, albo hyalina, parum nitida, anfractibus 4, nequaquam angulatis, quorum 2 apicales, vitrei, læves, penultimo et ultimo apud

1 Monog. Vitrinella, 1850, pp. 1-10 (gen. propr.); Cat. Shells Panama, 1852, p. 184.

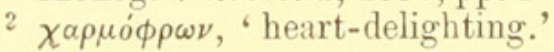


suturas depressis, deinde ventricosulis, undique sub lente pulcherrime et arctissime cancellatis, cancillis perminutis, apertura rotunda, peristomate tenui. Alt. $\cdot 75$, diam. $1 \cdot 5 \mathrm{~mm}$.

Hab.-Gulf of Oman, lat. $24^{\circ} 58^{\prime}$ N., long. $56^{\circ} 54^{\prime}$ E., 156 fathoms.

A most recherché little species, four-whorled, the two last being somewhat roundly depressed suturally; the whorl surface, smooth to the naked eye, is really most delicately shagreened with microscopic cancellations. It is of decidedly rare occurrence.

18. Cyclostrema placens (Melvill \& Standen). Pl. III, Figs. 6, 6a. Adeorbis placens, Melvill \& Standen: Proc. Zool. Soc., vol. ii (1901), p. 373 , pl. xxii, fig. 15 .

Hab.-Gulf of Oman, lat. $24^{\circ} 55^{\prime}$ N., long. $57^{\circ} 35^{\prime}$ E., 205 fathoms; also lat. $24^{\circ} 58^{\prime} \mathrm{N}$., long. $56^{\circ} 54^{\prime}$ E., 156 fathoms.

A minute, depressed, umbilicate glassy species, apparently quite smooth, but in the most frequent form, which we therefore take as typical, close microscopical concentric spiral lines occur on the upper portion of the whorls.

Var. complanata, Melvill \& Standen (loc. cit., p. 373).

Hab.-Reshire, Persian Gulf.

Surface entirely smooth. This occurred but rarely, and may possibly constitute a distinct species. Till fresh material is found, however, it is the prudent course to place it here.

\section{Subgenus II : LYDIPHNIS, ${ }^{1}$ nov.}

Testa profunde umbilicata, discoidalis, alba, tenuis, anfractus 4, quorum apicalis parvus, vitreus, cæteri undique concentrice tenuilirati, ultimus rectus, tribus carinis acutissimis præditus, quorum superior carina extra labrum projecta porrectionem trialatam præbet.

Type: Cyclostrema euchilopteron, M. \& S.

19. Cyclostrema euchilopteron, M. \& St. Pl. III, Figs. 7, $7 a$. Cyclostrema euchilopteron, Melvill \& Standen : Ann. \& Mag. Nat. Hist., vol. xii (1903), p. 292, pl. xx, fig. 7.

$H a b .-G u l f$ of Oman, lat. $24^{\circ} 58^{\prime} \mathrm{N}$., long. $56^{\circ} 54^{\prime}$ E., 156 fathoms.

The squarely-built body-whorl, with three strong keels, most prominently ridged, acutely projecting, and terminating in a triangularly winged extension of the upper part of the outer lip, presents, I think, characters that merit subgeneric distinction. In all probability $C$. Verreauxii, Fischer, ${ }^{2}$ from California, would come under the same category, subgenerically.

\section{Subgenus III: DELPHINOIDEA, Brown. ${ }^{3}$}

20. Cyclostrema eumares, Melvill. Pl. III, Figs. 4, $4 a$. Cyclostrema eumares, Melvill: Proc. Malac. Soc., vol. vi (1904), p. 158, pl. $\mathrm{x}$, figs. 1, 1 a. 
Hab.-Gulf of Oman, lat. $24^{\circ} 58^{\prime} \mathrm{N}$., long. $56^{\circ} 54^{\prime}$ E., 156 fathoms.

A smooth, umbilicate, globular species, the umbilicar region being excavate, thrice spirally lirate, decussate and crenulate at the points of junction of the longitudinal liræ; beyond these spiral lirations the base is scratched with what may be lines of growth.

Allied to C. Watsoni, Tryon (Man. Conch., vol. x, p. 94, pl. xxxii, figs. 81, 82), which was described by Boog Watson as sulcatum (Exp. Challenger, vol. $\mathrm{xv}$, pl. viii, fig. 11), but this name had been already appropriated by A. Adams.

\section{Cyclostrema euporetum, Melvill.}

Cyclostrema eupoietum, Melvill : Proc. Malac. Soc., vol. vi (1904), p. 159 , pl. x, fig. 2 .

Hab.-Gulf of Oman, lat. $24^{\circ} 58^{\prime}$ N., long. $56^{\circ} 54^{\prime}$ E., 156 fathoms.

A depressedly globular, very small species, closely spirally lirately sulcate, umbilicus partly covered by the lingular peristomatal process. Probably a member of this section, but, the operculum and soft parts being still unknown, also conchologically akin to Leptothyra, in the family Turbinidæ.

Subgenus IV: DARONIA, A. Adams. ${ }^{1}$

22. Cyclostrema subdisunnctum, H. Adams.

Cyclostrema subdisjunctum, H. Adams: Proc. Zool. Soc., 1868, p. 293, pl. xxviii, fig. 8 .

Hab.-Persian Gulf, Gulf of Oman, Maskat; 15 fathoms, muddy sand and loose stones. Always local, the range of distribution is a wide one, embracing Ceylon, to the Andaman Isles, at which last place I have received it from the late $\mathrm{Mr}$. George $\mathrm{H}$. Booley, of Port Blair.

The large size, 10 to 12 millimetres in diameter, obliquely rude contour, wide umbilicus, some spiral ribs, and, above all, the evolute body-whorl, amply distinguish this very curious species.

\section{Genus MICROTHYCA, A. Adams. ${ }^{2}$}

Microthyca crenellifera (A. Adams).

Isander crenelliferus, A. Adams: Ann. \& Mag. Nat. Hist., vol. ix (1862), p. 296.

Cyclostrema (Microtheca) crenellifera, A. Adams: Sowerby's Thes. Conch., vol. iii, p. 254, pl. 255, figs. 41, 42 (as Microthyca). Hab.-Bombay (A. Abercrombie).

Originally described as from Japan, this very interesting form is only known as Indian by one specimen found in shell-sand collected near Bombay. We have but little doubt it is specifically the same, being a shining white little shell, flattened and slightly angular above, with wide spire, and crenulated round the umbilicar region.

1 Sowerby's Thesaurus Conch., vol. iii (1864), p. 252.

2 Ann. \& Mag. Nat. Hist., vol. xi (1863), p. 264. 
It will be observed that this genus was designated by its author Microthyca on the plate and Microtheca in the text, as usually written, sut if derived from $\mu \iota \kappa \rho o s, ~ \theta \dot{\eta} \kappa \eta$, no doubt the latter is the more correct rendering.

\section{Genus LEUCORHYNCHIA, Crosse. ${ }^{1}$ \\ Leucorhynchia Crossei, Tryon.}

Leucorhynchia Crossei, Tryon: Man. Conch., vol. x (1888), p. 106, pl. $\mathrm{xxxv}$, figs. $86 a, 86 b$.

Hab.-Gulf of Oman, lat. $24^{\circ} 58^{\prime}$ N., long. $56^{\circ} 54^{\prime}$ E., 156 fathoms. I cannot separate these specimens from the Singapore species as sollected by Mr. Archer, and described by the late G. W. Tryon in 1888. The only difference, indeed, between $L$. Crossei and the typical L. caledonica, Crosse, is the absence of a peripheral angle around the body-whorl of the former. The examples, not at all infrequent in shell-sand from the above locality, are all uniformly white, shining, without any striation or marking whatsoever, perfectly smooth, subglobose, whorls $3-4$, with continuous peristome, thickened basally and produced into a lingual callosity that very nearly closes over the umbilicus.

\section{Genus MÖRCHIA, A. Adams. ${ }^{2}$}

\section{Mörchia Mokeleti, Fischer.}

Mörchia Moreleti, Fisch.: Journ. de Conch., 1877, p. 202, pl. x, fig. 1. Hab.-Gulf of Oman, lat. $24^{\circ} 58^{\prime}$ N., long. $56^{\circ} 54^{\prime}$ E., 156 fathoms. One of the smallest and most wonderful of shells. It is well figured by Fischer, and reproduced equally satisfactorily by Tryon (Man. Conch., vol. $\mathrm{x}$, pl. $\mathrm{xxxv}$, figs. 80-82). Only measuring two millimetres in diameter, it presents a quaint appearance, the shell being depressed, carinated, the keels furnished with a fimbriately crenate edge ; below, the form is like a small Ammonite, the whole coil being plainly seen in the unusually wide umbilicar region; the aperture is almost reversed, as in Anostoma. This very probably may be a distinct species; it is less in diameter by one-third than Fischer's type; but it is perhaps best at present not to differentiate it further.

\section{Family LIOTIID曆.}

\section{Genus LIOTIA, Gray. ${ }^{3}$}

Only three species of this family and genus have yet been detected in the Persian Gulf region, and all occur very rarely and locally.

\section{Liotia cidaris (Reeve).}

Delphinula cidaris, Reeve: Conch. Icon., vol. i, pl. v, fig. 27 ; Proc. Zool. Soe., 1843, p. 143.

Hab.-Angrias Bank, off coast of Bombay. Collected by Captain W. A. Tindall, of s.s. "Patrick Stewart."

1 Journ. de Conch., 1867, p. 319.

2 Ann. \& Mag. Nat. Hist., vol. v (1860), p. 301. (Type, M. obvoluta, A. Adams.)

3 Synopsis Brit. Mus., 1840; Proc. Zool. Soc., 1847, p. 145. 
2. Liotia echinacantha, Melvill \& Standen.

Liotia echinacantha, Melvill \& Standen: Ann. \& Mag. Nat. Hist., vol. xii (1903), p. 293, pl. xx, fig. 9 .

Hab.-Persian Gulf; Gulf of Oman, near Maskat, 10-15 fathoms.

This very beautiful shell, which occurred in some numbers at the above locality, is noticeable for its fluted spines, the nearest ally perhaps being $L$. Briareus, Dall, which I know only by the figure and description, ${ }^{1}$ but that seems a species of even more ornate character and sculpture. Both these species, echinacantha and Briareus, may belong to the subgenus Arene, but the present new form, at all events, possesses no scarlet radiating coloration on the whorls.

3. Liotia romalea, Melvill \& Standen.

Liotia romalea, Melvill \& Standen: Ann. \& Mag. Nat. Hist., vol. xii (1903), p. 293, pl. xx, fig. 8 .

Hab.-Persian Gulf, Sheikh Shuaib Island, 10 fathoms; Maskat, 10-15 fathoms; also Gulf of Oman, lat. $23^{\circ} 30^{\prime}$ N., long. $57^{\circ} 10^{\prime}$ E., 10 fathoms, and lat. $24^{\circ} 58^{\prime} \mathrm{N}$., long. $56^{\circ} 54^{\prime} \mathrm{E} ., 156$ fathoms, in shell-sand.

A typical Liotia, with obscurely five-angled and thickened peristome, and cancellated whorls, the last whorl thrice spirally keeled.

It remains only to say that Adeorbis, of which genus but two exponents have yet been noted from these seas, is now by universal consent removed from the proximity of the Cyclostrematidæ to a place amongst the Tænioglossa, near the Skeneidæ and Litiopidæ.

\section{EXPLANATION OF PLATE III.}

$\begin{array}{cccl}\text { Figs. 1, 1a. } & \text { Cyclostrema } 5 \text {-carinatum, n.sp. } \\ ,, & 2,2 a . & , & \text { charmophron, n.sp. } \\ ,, & 3,3 a . & , & 9 \text {-carinatum, n.sp. } \\ ,, & 4,4 a . & , & \text { eumares, Melv. } \\ ,, & 5,5 a . & , & \text { solariellum, Melv. } \\ ,, & 6,6 a . & ,, & \text { placens, M. \& St. } \\ ,, & 7,7 a . & , & \text { euchilopteron, M. \& St. } \\ ,, & 8,8 a . & ,, & \text { Prestoni, n.sp. }\end{array}$

1 Bull. Mus. Comp. Zool. Harvard, vol. xviii (1889), p. 388, pl. xxiv, figs. 5, $5 a$. 

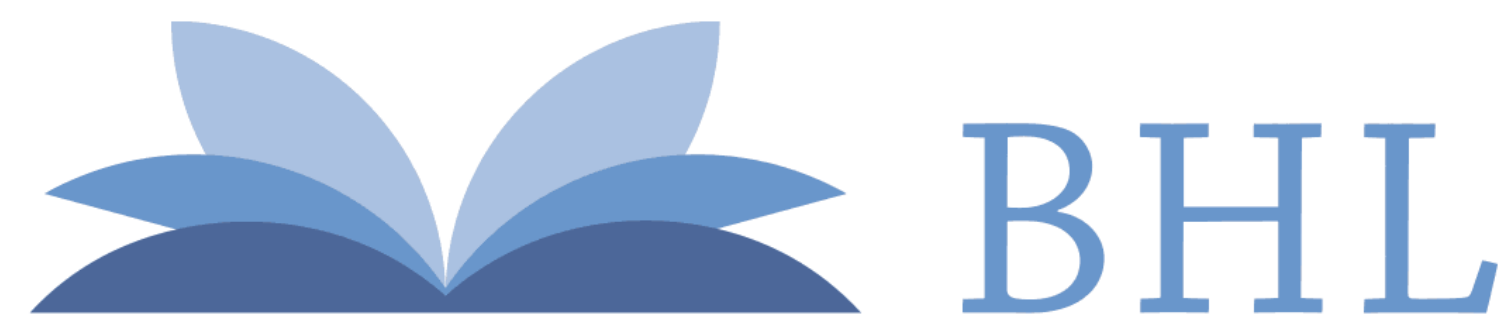

\section{Biodiversity Heritage Library}

Melvill, James Cosmo. 1906. "A REVISION OF THE SPECIES OF

CYCLOSTREMATIDÆ AND LIOTHDÆ OCCURRING IN THE PERSIAN GULF AND NORTH ARABIAN SEA." Proceedings of the Malacological Society of London 7, 20-28.

View This Item Online: $\underline{\text { https://www.biodiversitylibrary.org/item/53746 }}$

Permalink: https://www.biodiversitylibrary.org/partpdf/202907

\section{Holding Institution}

Smithsonian Libraries

\section{Sponsored by}

Smithsonian

\section{Copyright \& Reuse}

Copyright Status: Public domain. The BHL considers that this work is no longer under copyright protection.

This document was created from content at the Biodiversity Heritage Library, the world's largest open access digital library for biodiversity literature and archives. Visit BHL at https://www.biodiversitylibrary.org. 